\title{
CONTENTS
}

\section{Food Technology}

Marcela Morales, Karol Zapata, Carlos A. Sagaste, Alberto A. Angulo, Benjamín Rojano

Optimization of the ultrasound-assisted extraction of polyphenol, mangiferin, and its antioxidant expression in mango peel (Mangifera indica) using response surface methodology . . . . . . . . . . .

Marta Burzyńska, Dorota Piasecka-Kwiatkowska, Ewa Springer

Allergenic properties of Polish nectar honeys $\ldots \ldots \ldots \ldots \ldots \ldots \ldots \ldots \ldots \ldots \ldots \ldots \ldots \ldots \ldots$.

Olga Grygorieva, Svitlana Klymenko, Olena Vergun, Erika Mňahončáková, Ján Brindza,

Margarita Terentjeva, Eva Ivanišová

Evaluation of the antioxidant activity and phenolic content of Chinese quince (Pseudocydonia sinensis

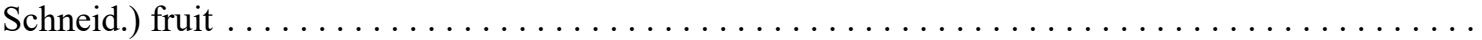

Katarzyna Grzelak-Błaszczyk, Andrzej Czarnecki, Robert Klewicki

The effect of osmotic dehydration on the polyphenols content in onion $\ldots \ldots \ldots \ldots \ldots \ldots \ldots$

Camila Carvalho, Alessandra Pagani, Alan Teles, Jucenir Santos, Tatiana Pacheco,

Ranulfo Combuca Junior, Magali Pozza

Jamelão capsules containing bioactive compounds and its aplication in yoghurt $\ldots \ldots \ldots \ldots \ldots$

Carmo Serrano, Margarida Sapata, M. Conceição Oliveira, André Gerardo, Cláudia Viegas

Encapsulation of oleoresins for salt reduction in food $\ldots \ldots \ldots \ldots \ldots \ldots \ldots \ldots \ldots \ldots \ldots \ldots$

Piotr Sałek, Wiesław Przybylski, Danuta Jaworska, Lech Adamczak, Dorota Zielińska,

Artur Gluchowski

The effects on the quality of poultry meat of supplementing feed with zinc-methionine complex ....

Sharmineh Sharafi, Leila Nateghi, Orang Eyvazzade, Maryam Taj Abadi Ebrahimi

The physicochemical, texture hardness and sensorial properties of ultrafiltrated low-fat cheese con-

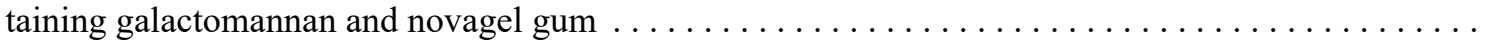

Barbara Biesiada-Drzazga, Dorota Banaszewska, Karolina Wielogórska, Sabina Kaim-Mirowski The effect of the genetic origin of hens on selected egg traits

\section{Human Nutrition}

\section{Joanna Mikołajczyk-Stecyna, Anna M. Malinowska, Agata Chmurzynska}

Polymorphism of TAS2R3, TAS2R5, TAS2R19, and TAS2R50 genes and bitter food intake frequency in elderly woman

Malgorzata Dobrzyńska, Juliusz Przysławski

The relationship between serum uric acid concentration and cardiovascular risk factors in normotensive postmenopausal women with dyslipidemia 